\title{
SHROOM2 Gene
}

National Cancer Institute

\section{Source}

National Cancer Institute. SHROOM2 Gene. NCI Thesaurus. Code C118551.

This gene may play a role in the modulation of cell morphology. 